\title{
LEVANDO A SÉRIO OS DIREITOS POLÍTICOS FUNDAMENTAIS: INELEGIBILIDADE E CONTROLE DE CONVENCIONALIDADE*
}

\author{
Luiz Magno Pinto Bastos Júnior e Rodrigo Mioto dos Santos
}

\section{RESUMO}

EM tempos de "Fichalimpismo" E dE EXCESSO dE INTERVENC̣ÃO JUDICIAL NA DEFINIC̣ÃO DAS REGRAS DO JOGO DEMOCRÁTICO, IMPÕE-SE UMA RENOVADA REFLEXĀO SOBRE A DIMENSĀO JUSFUNDAMENTAL DOS DIREITOS POLÍTICOS, EM ESPECIAL, EM RELAÇĀO AO DIREITO FUNDAMENTAL DE SER ELEITO. O OBJETIVO GERAL DESTE ARTIGO CONSISTE EM DEMONSTRAR QUE OS CASOS DE INELEGIBILIDADES INFRACONSTITUCIONAIS DISCIPLINADOS ENTRE NÓS PELA LEI COMPLEMENTAR N. 64/90 (DORAVANTE LC N. 64/90) NÄO SE COMPATIBILIZAM COM A GARANTIA CONVENCIONAL PREVISTA NO ART. 23, ITEM 2, DA CONVENÇĀO AMERICANA de Direitos humanos (doravante Convençāo AMERICANA OU CONVENÇÃO), QUE SÓ ADMITE QUE ELES SEJAM RESTRINGIDOS "EXCLUSIVAMENTE POR MOTIVOS DE IDADE, NACIONALIDADE, RESIDÊNCIA, IDIOMA, INSTRUÇÃO, CAPACIDADE CIVIL OU MENTAL, OU CONDENAÇÃO, POR JUIZ COMPETENTE, EM PROCESSO PENAL." DIANTE DESTA INCOMPATIBILIDADE, OS JUÍZES NACIONAIS ENCONTRAM-SE AUTORIZADOS A NEGAR VIGÊNCIA À LEI NACIONAL E A FAZER VALER A PROTEÇÃO PREVISTA NA CONVENÇÃO, A DESPEITO DE EXISTIR DECISĀO PROFERIDA PELO STF EM CONTROLE ABSTRATO DE CONSTITUCIONALIDADE REVESTIDA DE FORCุA VINCULANTE.

\section{PALAVRAS-CHAVE}

CONTROLE DE CONVENCIONALIDADE; DIREITOS POLÍTICOS FUNDAMENTAIS; INELEGIBILIDADES INFRACONSTITUCIONAIS; LeI dA Ficha Limpa; Supremo Tribunal Federal.
TAKING THE POLITICAL RIGHTS SERIOUSLY: INELEGIBILITIES AND CONTROL OF CONVENTIONALITY

\section{ABSTRACT}

THE EMERGENCE OF A STRONG LEVEL OF MORALIZATION AND INTERFERENCE OF THE JUDICIAL POWER ON THE DEMOCRATIC GAME RULES DEMANDS THE REFLECTION ABOUT THE FUNDAMENTAL DIMENSION OF THE POLITICAL RIGHTS, SPECIALLY, THE RIGHT TO BE VOTED. IN THIS ARTICLE, I ARGUE THAT ALMOST ALL THE HYPOTHESIS DEFINED BY THE BRAZILIAN INELIGIBILITIES ACT (LEI COMPLEMENTAR NR. 64/90) ARE NOT COMPATIBLE WITH THE GUARANTEE ENSURED BY THE ARTICLE 23 OF AMERICAN CONVENTION ON HUMAN RIGHTS, WHEREBY ALL THE CITIZENS SHALL ENJOY "THE RIGHT AND OPPORTUNITY" (ART. 23) TO "BE ELECTED IN GENUINE PERIODIC ELECTIONS" (ART. 23, 1.B), AND THE EXERCISE OF THIS RIGHT SHOULD BE RESTRICT "ONLY ON THE BASIS OF AGE, NATIONALITY, RESIDENCE, LANGUAGE, EDUCATION, CIVIL AND MENTAL CAPACITY, OR SENTENCING BY A COMPETENT COURT IN CRIMINAL PROCEEDINGS" (ART. 23.2). BECAUSE OF THIS, ALL THE DOMESTIC JUDGES ARE AUTHORIZED TO DENY VALIDITY TO THE NATIONAL STATUTE, AND APPLY DIRECTLY THE CONVENTIONAL GUARANTEE, DESPITE THE FACT THAT THE BRAZILIAN SUPREME COURT HAD UPHOLD THE INELIGIBILITIES ACT BY A DECISION ENDOWED WITH BINDING FORCE FOR ALL THE NATIONAL JUDGES.

\section{KEYWORDS}

CONTROL OF CONVENTIONALITY; POLITICAL RIGHTS; INELEGIBILITIES ACT; "FICHA LIMPA" ACT; BRAZILIAN SUPREME COURT. 


\section{INTRODUÇÃO}

Os manuais de direito eleitoral e direito processual eleitoral brasileiros permanecem em um silêncio eloquente quanto à Convenção Americana de Direitos Humanos. Não existe uma única referência à garantia insculpida no art. 23 que consagra especificamente os direitos políticos como parte integrante do Sistema Interamericano de Proteção (COÊLHO, 2012; CÂNDIDO, 2012; COSTA, 2013; GOMES, 2013; ZILIO, 2012) ${ }^{1}$. Essa omissão, no entanto, não causa estranheza, já que a própria temática dos direitos políticos como direitos fundamentais carece de maiores reflexões, não somente por parte da doutrina especializada, mas, sobretudo, pelas Cortes eleitorais (GUEDES, 2013, p. 659-674; ESPÍNDOLA, 2013, p. 169-174).

No direito pátrio, costuma-se falar em uma teoria geral das inelegibilidades consistentes na configuração de situações que "impedem o exercício do ius honorum em determinada eleição” (MENDES, 1994, p. 163). Este conjunto de restrições derivariam do princípio da autenticidade eleitoral, posto que relacionado à "fidedignidade da representação política" (SALGADO, 2010, p. 57). Os impedimentos (provisórios ou permanentes) encontram-se expressamente consignados no texto constitucional (art. 14, $\S \S 4^{\circ}$ e $8^{\circ}$, da CF) e na legislação complementar (LC n. 64/90, art. $1^{\circ}$ ).

Entre nós, o direito fundamental de concorrer aos pleitos eleitorais está sujeito ao preenchimento de um conjunto de condições de habilitação (condições de elegibilidade) e pode ser afastado diante da existência de quaisquer das causas de inelegibilidade, muitas das quais se trasvestem de sanções de inabilitação. De acordo com a legislação brasileira, estas sanções de inabilitação representam efeitos secundários (ou indiretos), definidos pela própria lei eleitoral, em relação à prática de condutas que estariam a revelar falta de "moralidade para o exercício de mandato", ou ainda, que poderiam configurar quebra de "legitimidade das eleições" (art. 14, § $9^{\circ}$ da CF).

Se a lei de inelegibilidades brasileira, na redação originária de maio de 1990 (LC n. 64/90), já era pródiga na definição de hipóteses de inelegibilidade (para além da exclusão dos inalistáveis, previa originariamente oito situações geradoras de impedimento legal); com a promulgação da Lei Complementar n. 135, de 4 de junho de 2010 (doravante LC n. 135/2010), popularizada como Lei da Ficha Limpa, estas hipóteses multiplicaram-se para 16.

A alteração legislativa decorreu de um grande movimento popular de combate à corrupção eleitoral e foi desencadeada por iniciativa popular que reuniu mais de 1,5 milhão de assinaturas de eleitores espalhados em todos os Estados da Federação brasileira. Esta indiscutível pressão popular acabou por resultar em aprovação relâmpago desta norma sem que tenha sofrido alterações legislativas substantivas ao texto apresentado. E a despeito da exigência de anualidade para as alterações que modifiquem o processo eleitoral, conforme fixado pelo art. 16 da CF, o novo regramento foi parcialmente aplicado pela Justiça Eleitoral já nas eleições de 2010, situação que só foi revertida pelo Supremo Tribunal Federal no julgamento do RE n. 633.703 (Rel. Min. 
Gilmar Mendes), quando já ultimado o pleito eleitoral.

Instado uma vez mais a se manifestar sobre a referida norma, agora sobre a sua compatibilidade material com o texto constitucional, em 9 de novembro de 2011 a Corte Suprema brasileira julgou improcedente a Ação Direta de Inconstitucionalidade n. 4.578. Nesta oportunidade, proferiu pronunciamento com eficácia vinculante que reafirmou a integral constitucionalidade das alterações determinadas pela LC n. 135/2010 no sistema de inelegibilidades infraconstitucionais.

Ocorre que, por ser signatário da Convenção Americana sobre Direitos Humanos, desde a sua promulgação interna decorrente do Decreto n. 678, de 6 de novembro de 1992, passou a viger na ordem jurídica interna a garantia expressa de que todos os cidadãos devem gozar do direito "de ser eleitos em eleições periódicas autênticas" (art. 23, item 1, letra "b”), direitos estes que só poderiam ser restringidos com base nas causas definidas no próprio texto convencional, vale dizer, "exclusivamente por motivos de idade, nacionalidade, residência, idioma, instrução, capacidade civil ou mental, ou condenação, por juiz competente, em processo penal.” (art. 23, item 2). O dispositivo convencional foi taxativo ao restringir a liberdade de conformação dos Estados-Parte. As restrições aos direitos políticos enunciados no art. 23, item 1, só poderiam ser promulgadas em estrita observância das hipóteses mencionadas no texto (isto em face do termo "exclusividade").

Independentemente do status que se atribua a esta norma entre nós (BASTOS JR; GONÇALVES, 2013, p. 2393-2396), é inegável que a mesma foi devidamente internalizada na ordem jurídica e que, em face do disposto no art. $5^{\circ}, \S 2^{\circ}$, da Constituição Brasileira, goza de um indiscutível caráter de fundamentalidade no plano doméstico (SARLET, 2013; 2015, p. 79-83). E, mais ainda, de acordo com o que vem sendo reconhecido no plano supranacional pela Corte Interamericana de Direitos Humanos, todos os órgãos judiciários domésticos possuem um dever de remover os óbices internos à plena aplicação da norma internacional mais benéfica ao ser humano (SAGÜES, 2010, p. 120-122), razão pela qual devem engajar-se em um esforço coordenado de controle de convencionalidade das normas domésticas, tendo em vista a máxima aplicação dos standards mínimos de proteção internacional dos direitos humanos (BASTOS JR; CAMPOS, 2011; MAZZUOLI, 2013, p. 4-20). Se entre nós esta prática não é muito difundida, em outras jurisdições latino-americanas constatam-se importantes avanços no tocante à consideração dada pelas Cortes Constitucionais ao sistema interamericano de direitos humanos (AGUILAR, 2013).

Nesse sentido, o presente artigo tem por objetivo confrontar as hipóteses legais definidas na LC n. 64/90 com a garantia prevista no art. 23.2 da Convenção Americana de Direitos Humanos.

Essa compatibilidade (ou sua ausência) será analisada a partir da confrontação entre a legislação brasileira (na forma como é compreendida pelo Supremo Tribunal Federal) com a jurisprudência da Corte Interamericana de Direitos Humanos (doravante 
CorteIDH ou Corte). A análise terá como perspectiva a identificação dos standards interpretativos fixados nos precedentes estudados que permitem a compreensão do conteúdo e do alcance a ser atribuído aos dispositivos e obrigações convencionais que se impõem aos Estados signatários.

É desta forma porque o marco normativo supranacional não se restringe à literalidade da norma convencional, mas deve ser analisado à luz de seu contexto normativo de significação, em outras palavras, em conjunto com o acervo jurisprudencial emanado da Corte responsável pela sua adjudicação (como intérprete qualificado de seus dispositivos) e pela interpretação dada pelos órgãos judiciais dos diferentes países igualmente signatários deste mesmo diploma internacional. Afinal de contas, a norma internacional deve ser interpretada de acordo com seu contexto (LUPI; BASTOS JR, 2008).

Especificamente em relação à regra em comento, existem dois importantes precedentes da CorteIDH que enfrentaram especificamente a abrangência dessa garantia convencional, um (o caso Castañeda Gutman vs. Estados Unidos Mexicanos, de 6 de agosto de 2008) em que se discutiu a possibilidade de se assegurar a candidatura independente à Presidência como decorrência direta da garantia convencional prevista no art. 23.1.b; e outro (o caso López Mendoza vs.Venezuela, de 11 de setembro de 2011) em que se discutiu especificamente a aplicação de sanções de inabilitação em processos administrativos (apuração de sanção disciplinar e regularidade na execução orçamentária), afirmando que esta hipótese de suspensão de direitos políticos não estaria autorizada pelo art. 23.2 da Convenção.

Essas decisões exigem que se desencadeie uma profunda revisão da compreensão nacional sobre a natureza de jusfundamentalidade dos direitos políticos, bem como sobre os limites que se impõem à restrição de tais direitos. A situação é tanto mais premente quando se constata que praticamente todo o sistema de inelegibilidades infraconstitucionais, em face das alterações determinadas pela LC n. 135/2010, não sobrevive à análise de compatibilidade com a Convenção Americana.

A fim de explorar este tema, o presente artigo está estruturado nos seguintes termos: na primeira parte, será feita uma breve incursão sobre as inelegibilidades infraconstitucionais do direito brasileiro e os argumentos subscritos pelo Supremo Tribunal Federal para afastar a arguição de inconstitucionalidade dirigida contra a LC n. 135/2010; na segunda parte, serão apresentados os casos analisados pela CorteIDH, a fim de que seja apresentada sua visão sobre o alcance da garantia e sobre os limites à atividade de conformação do legislador nacional; e, na terceira e última parte, será feita a análise de (des)conformidade entre o diploma doméstico e os standards interpretativos emanados da CorteIDH em relação aos arts. 23.1.b e 23.2 da Convenção Americana.

Espera-se, com esse esforço, discutir as inelegibilidades (e a exacerbação conferida ao Poder Judiciário por conta da Lei da Ficha Limpa) a partir de uma perspectiva ainda mais enfática quanto à crítica a ser endereçada ao novo arranjo institucional 
brasileiro. Afinal de contas, há de se levar a sério os direitos políticos fundamentais, a começar pela Corte Suprema brasileira.

\section{DAS INELEGIBILIDADES INFRACONSTITUCIONAIS E SUA INTERPRETAÇÃO pelo Supremo Tribunal Federal}

As inelegibilidades infraconstitucionais cominadas encontram sua justificação no próprio texto constitucional, vale dizer, no $\S 9^{\circ}$ do art. 14:

Lei complementar estabelecerá outros casos de inelegibilidade e os prazos de sua cessação, a fim de proteger a probidade administrativa, a moralidade para exercício de mandato considerada vida pregressa do candidato, e a normalidade e legitimidade das eleições contra a influência do poder econômico ou o abuso do exercício de função, cargo ou emprego na administração direta ou indireta.

A fim de dar concretude a este comando constitucional, foi editada a LC n. 64/90, que trata sobre as inelegibilidades. Em sua redação originária, a norma elencou em seu art. $1^{\circ}$ um conjunto de situações que, presentes, importariam em restrição temporária ao ius sufragii dos cidadãos. As restrições foram aqui agrupadas em cinco categorias, para fins de análise, como se verá adiante.

Pois bem, a LC n. 135/2010 operou um conjunto muito expressivo de alterações em relação às inelegibilidades: (A) as hipóteses foram significativamente ampliadas (de oito para dezesseis); (B) os efeitos decorrentes de decisões judiciais passaram a ser antecipados (ou seja, a Lei dispensou o trânsito em julgado da decisão, admitindo que a decisão por órgão colegiado seria suficiente para a restrição aos direitos políticos); (C) os prazos de suspensão dos direitos políticos foram ampliados (e uniformizados) para 8 (oito) anos; e, por fim, (D) algumas hipóteses tiveram a sua redação alterada.

O grupo das hipóteses de inelegibilidades pode ser assim descrito (alterações foram destacadas em itálico):

(i) aqueles que não estiverem no gozo dos direitos políticos (alínea “a”) (sem alterações);

(ii) os agentes políticos, parlamentares e chefes do Executivo, que tenham tido seus mandatos cassados pelo Parlamento (inc. I, alíneas "b" $\mathrm{e}$ " $\mathrm{c}$ ") e que tenham renunciado ao seu mandato desde o oferecimento de petição que pudesse resultar na pena de cassação (art. I, alínea "k”) (prazo ampliado para 8 anos);

(iii) aqueles agentes que tenham sido condenados em determinados processos 
judiciais de índole eleitoral (inc. I, “d”, “j”, “n” e " $p$ ”), criminal (inc. I, “e”, ampliação do rol dos crimes) e civil (inc. I, "h", "l”) (hipóteses acrescidas e prazos ampliados);

(iv) aqueles que tenham sido sancionados em processos administrativos (inc. I "f”, "g”, “i”, “m”, “o” " “q”) (prazos ampliados); e

(v) aqueles que não tenham se desincompatibilizado de determinados cargos públicos no prazo fixado pela legislação (incs. II a VII) (sem alterações).

Com tantas e significativas modificações em tema tão sensível, inevitável que a LC n. 135/2010 fosse submetida ao controle abstrato de constitucionalidade perante o Supremo Tribunal Federal (ADI n. 4.578 e ADC n. 29 e n. 30). ${ }^{2}$ Razão pela qual diversos aspectos que serão objeto de consideração neste trabalho foram especificamente enfrentados pela Corte Constitucional, conforme será visto na sequência:

Quanto à eficácia retroativa da norma decorrente do fato de que a Lei ampliou os prazos de suspensão para 8 (oito) anos (alterando a regra anterior que previa prazos de 3 (três), 4 (quatro) e 5 (cinco) anos; inclusive, a própria coisa julgada) e que passou a abranger situações que, anteriormente à sua edição, não eram elencadas no rol das causas de inelegibilidade (A), assim se pronunciou a Corte Suprema:

1. A elegibilidade é a adequação do indivíduo ao regime jurídico - constitucional e legal complementar - do processo eleitoral, razão pela qual a aplicação da Lei Complementar n. 135/10 com a consideração de fatos anteriores não pode ser capitulada na retroatividade vedada pelo art. $5^{\circ}$, XXXVI, da Constituição, mercê de incabível a invocação de direito adquirido ou de autoridade da coisa julgada (que opera sob o pálio da cláusula rebus sic stantibus) anteriormente ao pleito em oposição ao diploma legal retromencionado; subjaz a mera adequação ao sistema normativo pretérito (expectativa de direito). (destaque dos autores) (BRASIL, Supremo Tribunal Federal, ADI n. 4.578; ADC n. 29; ADC n. 30, 2012)

Quanto às restrições indevidas e aumento desproporcional das hipóteses de inelegibilidade (B), assim se pronunciou o Supremo Tribunal Federal:

2. A razoabilidade da expectativa de um indivíduo de concorrer a cargo público eletivo, à luz da exigência constitucional de moralidade para o exercício do mandato (art. 14, $\S 9^{\circ}$ ), resta afastada em face da condenação prolatada em segunda instância ou por um colegiado no exercício da competência de foro por prerrogativa de função, da rejeição de contas públicas, da perda de cargo público ou do impedimento do exercício de profissão por violação de dever éticoprofissional. [...] 
5. O direito político passivo (ius honorum) é possível de ser restringido pela lei, nas hipóteses que, in casu, não podem ser consideradas arbitrárias, porquanto se adequam à exigência constitucional da razoabilidade, revelando elevadíssima carga de reprovabilidade social, sob os enfoques da violação à moralidade ou denotativos de improbidade, de abuso de poder econômico ou de poder político.

6. O princípio da proporcionalidade resta prestigiado pela Lei Complementar $\mathrm{n}^{\circ}$ 135/10, na medida em que: (i) atende aos fins moralizadores a que se destina; (ii) estabelece requisitos qualificados de inelegibilidade e (iii) impõe sacrifício à liberdade individual de candidatar-se a cargo público eletivo que não supera os benefícios socialmente desejados em termos de moralidade e probidade para o exercício de referido munus publico.

7. O exercício do ius honorum (direito de concorrer a cargos eletivos), em um juízo de ponderação no caso das inelegibilidades previstas na Lei Complementar $\mathrm{n}^{\circ} 135 / 10$, opõe-se à própria democracia, que pressupõe a fidelidade política da atuação dos representantes populares.

8. A Lei Complementar n. 135/10 também não fere o núcleo essencial dos direitos políticos, na medida em que estabelece restrições temporárias aos direitos políticos passivos, sem prejuízo das situações políticas ativas.

9. O cognominado desacordo moral razoável impõe o prestígio da manifestação legítima do legislador democraticamente eleito acerca do conceito jurídico indeterminado de vida pregressa, constante do art. 14, § 9. ${ }^{\circ}$, da Constituição Federal. (destaque dos autores) (BRASIL, Supremo Tribunal Federal, ADI n. 4.578; ADC n. 29; ADC n. 30, 2012)

Especificamente em relação à presunção de inocência $(\mathrm{C})$, já que a Lei projeta efeitos sobre elegibilidade antes do trânsito em julgado das decisões judiciais (se contentando com as decisões proferidas por órgãos colegiados), foram esses os argumentos lançados pela decisão em tela:

3. A presunção de inocência consagrada no art. $5^{\circ}$, LVII, da Constituição Federal deve ser reconhecida como uma regra e interpretada com o recurso da metodologia análoga a uma redução teleológica, que reaproxime o enunciado normativo da sua própria literalidade, de modo a reconduzi-la aos efeitos próprios da condenação criminal (que podem incluir a perda ou a suspensão de direitos políticos, mas não a inelegibilidade), sob pena de frustrar o propósito moralizante do art. 14, § $9^{\circ}$, da Constituição Federal.

4. Não é violado pela Lei Complementar $n^{\circ} 135 / 10$ o princípio constitucional da vedação de retrocesso, posto não vislumbrado o pressuposto de sua aplicabilidade concernente na existência de consenso básico, que tenha inserido na consciência jurídica geral a extensão da presunção de inocência para o âmbito 
eleitoral. (BRASIL, Supremo Tribunal Federal, ADI n. 4.578; ADC n. 29; ADC n. 30, 2012)

Em relação à ofensa ao exercício do direito de renúncia parlamentar (D), a decisão restou assim ementada:

10. O abuso de direito à renúncia é gerador de inelegibilidade dos detentores de mandato eletivo que renunciarem aos seus cargos, posto hipótese em perfeita compatibilidade com a repressão, constante do ordenamento jurídico brasileiro (v.g., o art. 55, $\S 4^{\circ}$, da Constituição Federal e o art. 187 do Código Civil), ao exercício de direito em manifesta transposição dos limites da boa-fé. (BRASIL, Supremo Tribunal Federal, ADI n. 4.578; ADC n. 29; ADC n. 30, 2012)

Por fim, sobre a natureza das inelegibilidades (condição objetiva), que não se confunde com a sanção de suspensão de direitos políticos (E), o pronunciamento da Corte deu-se nos seguintes termos:

11. A inelegibilidade tem as suas causas previstas nos $\S \S 4^{\circ}$ a $9^{\circ}$ do art. 14 da Carta Magna de 1988, que se traduzem em condições objetivas cuja verificação impede o indivíduo de concorrer a cargos eletivos ou, acaso eleito, de os exercer, e não se confunde com a suspensão ou perda dos direitos políticos, cujas hipóteses são previstas no art. 15 da Constituição da República, e que importa restrição não apenas ao direito de concorrer a cargos eletivos (ius honorum), mas também ao direito de voto (ius sufragii). Por essa razão, não há inconstitucionalidade na cumulação entre a inelegibilidade e a suspensão de direitos políticos. (BRASIL, Supremo Tribunal Federal, ADI n. 4.578; ADC n. 29; ADC n. 30, 2012)

Ao final, a Corte julgou os pedidos formulados na ação de inconstitucionalidade improcedentes e, por consequência, procedentes os pedidos deduzidos nas ações declaratórias de constitucionalidade.

Em face da natureza vinculante dirigida a todos os órgãos do Poder Judiciário e do Poder Executivo (art. 102, § $2^{\circ}$, da Constituição Federal), de acordo com a ordem jurídica brasileira, os diferentes órgãos judiciais encontram-se impedidos de suspender a aplicabilidade de quaisquer dispositivos da LC n. 135/2010, sob o argumento de que ofendem a Constituição. No entanto, defende-se adiante que o juiz nacional, apesar da decisão do Supremo Tribunal Federal, deverá deixar de aplicar esta norma tendo em vista a frontal colisão com as garantias convencionais insculpidas no art. 23.1.b e 23.2 da Convenção Americana. 


\section{Do AlCANCE do DiReito de SER VOTAdo PREVisto NA CONVENÇÃo AMERICANA (ART. 23.I.B C/C O ART. 23.2) E AS OBRIGAÇÕES DOS Estados-PARTE}

No âmbito do Sistema Interamericano de Direitos Humanos (doravante SIDH), o vínculo necessário entre democracia e direitos humanos é assinalado nos principais pronunciamentos da CorteIDH, para quem os direitos políticos "propician el fortalecimiento de la democracia y el pluralismo político", nos termos do pronunciamento nos casos Castañeda Gutman v. Estados Unidos Mexicanos (CorteIDH, 2008, § 141, p. 42) e Yatama vs. Nicaragua (CorteIDH, 2005, § 192, p. 88).

Estes direitos encontram-se expressamente contemplados na Convenção Americana de Direitos Humanos nos seguintes termos:

Artigo 23. Direitos políticos

1. Todos os cidadãos devem gozar dos seguintes direitos e oportunidades: [...]

b. de votar e ser eleitos em eleições periódicas autênticas, realizadas por sufrágio universal e igual e por voto secreto que garanta a livre expressão da vontade dos eleitores; e [...]

2. A lei pode regular o exercício dos direitos e oportunidades a que se refere o inciso anterior, exclusivamente por motivos de idade, nacionalidade, residência, idioma, instrução, capacidade civil ou mental, ou condenação, por juiz competente, em processo penal.

Ao empreender uma análise sobre o alcance dos direitos políticos na jurisprudência da CorteIDH e nos pronunciamentos da Comissão Interamericana de Direitos Humanos (doravante ComissãoIDH), Alberto Dalla Via (2011, p. 20-21) consigna que:

[...] el adecuado ejercicio de los derechos políticos consagrados en el artículo 23 de la CADH se vincula con la vigencia de sus derechos y libertades entre los cuales se encuentran asociados el derecho a la libertad de expresión (artículo 13); a las garantías judiciales (artículo 8); el derecho de reunión (artículo 15), a la libertad de asociación (artículo 16), el derecho a la protección judicial (artículo 25); el derecho de libertad de investigación, opinión, expresión y difusión (IV); el derecho de asociación (XXII) y reunión (XXI); y el derecho de justicia (XVIII) de la DADH.

Así lo ha entendido la Corte al sostener que: Los derechos políticos son derechos humanos de importancia fundamental dentro del sistema 
interamericano que se relacionan estrechamente con otros derechos consagrados en la Convención Americana, como la libertad de expresión, la libertad de reunión y la libertad de asociación y que, en conjunto, hacen posible el juego democrático. (Informe Haití, CIDH, 1990a, cap. I)

Em razão desse vínculo indissociável entre democracia e direitos humanos, a máxima realização da democracia participativa deve ser pautada por um feixe interpretativo estabelecido, primariamente, no próprio texto da Convenção. Fixadas estas premissas iniciais, convém tecer breves considerações sobre os precedentes da CorteIDH a fim de que se possa extrair deles os standards interpretativos a serem utilizados pelos togados na aplicação do juízo de compatibilidade vertical entre as normas domésticas e as convencionais (res interpretata) (FERRER, 2013, p. 688-693).

\section{I Análise do caso Castañeda Gutman vs. Estadoos Unidos Mexicanos (6 de} agosto de 2008). Direito À oportunidade de participaÇÃo E limites ao Estado O caso Castañeda Gutman vs. Estados Unidos Mexicanos foi julgado em 6 de agosto de 2008 e gravita, no que diz respeito especificamente ao objeto desse artigo, ao redor de dois aspectos fundamentais: a afirmação de que os Estados-Parte têm o dever de conferir aos cidadãos oportunidades efetivas para que os mesmos exerçam o direito a participar dos assuntos políticos (art. 23.1.b) e sobre a limitação do poder de conformação dos Estados no tocante à regulamentação dos direitos políticos que, para além das restrições explícitas definidas no art. 23.2, devem estar sujeitas ao crivo da proporcionalidade.

Os fatos submetidos à apreciação da Corte diziam respeito ao pedido de registro de candidatura individual e independente à Presidência da República, formulado pelo Sr. Castañeda Gutman ao órgão administrativo responsável pelos registros (Conselho Geral do Instituto Federal Eleitoral). O pedido foi negado sob o argumento de que somente os partidos políticos nacionais gozam da prerrogativa de solicitar o registro de candidaturas a mandatos eletivos. Contra essa decisão, o Sr. Castañeda Gutman ingressou, sem êxito, com recurso de amparo à Corte Regional Federal e recurso de cassação à Corte Suprema Mexicana (nesta última, com pedido de providência acautelatória). Os órgãos judiciais deixaram de conhecer do pedido formulado pelo Sr. Castañeda Gutman pois entendiam que não possuía legitimidade ativa para impugnar decisões do órgão administrativo federal (legitimidade confiada somente aos partidos políticos).

Ao propor a demanda perante a Corte, a ComissãoIDH postulou o reconhecimento de uma dupla violação aos direitos políticos da vítima: (1) o direito a um recurso judicial efetivo (art. 25 da Convenção) e (2) o direito concreto a ver registrada sua candidatura independente (art. 23.1.b da Convenção), já que a condição de filiação prévia a partido político não representava uma das exceções previstas pelo art. 23.2 
da Convenção. Em razão dos objetivos desse artigo, a análise do caso limitar-se-á ao segundo aspecto.

Pois bem, no que diz respeito à abrangência dos direitos políticos definidos no art. 23.1 da Convenção, a CorteIDH fixou alguns importantes balizamentos, chamando a atenção para a peculiaridade da obrigação dos Estados de assegurar aos cidadãos ampla oportunidade de participação na vida política. Deste precedente, extraem-se as seguintes diretrizes interpretativas:

145. El artículo 23 contiene diversas normas que se refieren a los derechos de la persona como ciudadano, esto es, como titular del proceso de toma de decisiones en los asuntos públicos, como elector a través del voto o como servidor público, es decir, a ser elegido popularmente o mediante designación o nombramiento para ocupar un cargo público. Además de poseer la particularidad de tratarse de derechos reconocidos a los ciudadanos, a diferencia de casi todos los demás derechos previstos en la Convención que se reconocen a toda persona, el artículo 23 de la Convención no sólo establece que sus titulares deben gozar de derechos, sino que agrega el término "oportunidades". Esto último implica la obligación de garantizar con medidas positivas que toda persona que formalmente sea titular de derechos políticos tenga la oportunidad real para ejercerlos. Como ya lo señalara este Tribunal anteriormente, es indispensable que el Estado genere las condiciones y mecanismos óptimos para que los derechos políticos puedan ser ejercidos de forma efectiva, respetando el principio de igualdad y no discriminación. (destaque dos autores) (CorteIDH, 2008, § 145, p. 43)

E ainda:

148. Por su parte, la participación política mediante el ejercicio del derecho a ser elegido supone que los ciudadanos puedan postularse como candidatos en condiciones de igualdad y que puedan ocupar los cargos públicos sujetos a elección si logran obtener la cantidad de votos necesarios para ello.

149. El derecho y la oportunidad de votar y de ser elegido consagrados por el artículo 23.1.b de la Convención Americana se ejerce regularmente en elecciones periódicas, auténticas, realizadas por sufragio universal e igual y por voto secreto que garantice la libre expresión de la voluntad de los electores. Más allá de estas características del proceso electoral (elecciones periódicas y auténticas) y de los principios del sufragio (universal, igual, secreto, que refleje la libre expresión de la voluntad popular), la Convención 


\section{Americana no establece una modalidad específica o un sistema}

electoral particular mediante el cual los derechos a votar y ser elegido deben ser ejercidos [...]. La Convención se limita a establecer determinados estándares dentro de los cuales los Estados legítimamente pueden y deben regular los derechos políticos, siempre y cuando dicha reglamentación cumpla con los requisitos de legalidad, esté dirigida a cumplir con una finalidad legítima, sea necesaria y proporcional; esto es, sea razonable de acuerdo a los principios de la democracia representativa. (destaque dos autores) (CorteIDH, 2008, $\S \S 148-149$, p. 43-44)

Ao reiterar a essencialidade dos direitos políticos, a CorteIDH reconheceu que o Estado-Parte goza de uma relativa liberdade de conformação para definir os modelos eleitorais (engenharias institucionais) a serem adotados, de forma que:

157. [...] la ley necesariamente tiene que establecer regulaciones que van más allá de aquellas que se relacionan con ciertos límites del Estado para restringir esos derechos, establecidos en el artículo 23.2 de la Convención. Los Estados deben organizar los sistemas electorales y establecer un complejo número de condiciones y formalidades para que sea posible el ejercicio del derecho a votar y ser votado. [...]

161. Como se desprende de lo anterior, la Corte estima que no es posible aplicar al sistema electoral que se establezca en un Estado solamente las limitaciones del párrafo 2 del artículo 23 de la Convención Americana. (CorteIDH, 2008, $\S \S 157$ e 161, p. 46 e 47)

No entanto, esta relativa liberdade de conformação não afasta a possibilidade de controle por parte da Corte Interamericana de Direitos Humanos,

161. [...] Sin embargo, las medidas que los Estados adoptan con el fin de garantizar el ejercicio de los derechos convencionales no están excluidas de la competencia de la Corte Interamericana cuando se alega una violación de los derechos humanos previstos en la Convención. Consecuentemente, la Corte debe examinar si uno de esos aspectos vinculados a la organización y reglamentación del proceso electoral y de los derechos políticos, la exclusividad de nominación de candidatos a cargos federales por parte de los partidos políticos, implica una restricción indebida a los derechos humanos consagrados en la Convención. (CorteIDH, 2008, § 161, p. 47)

Portanto, após reafirmar a sua competência para conhecer da alegada violação à Convenção, a CorteIDH passa a empreender um rigoroso controle de convencionalidade 
da lei mexicana aplicando os seguintes testes: a observância da reserva legal estrita (legalidade da medida restritiva, $\S \S 176$-179) e a aferição da inexistência de excesso com base nos postulados do princípio da proporcionalidade (finalidade, $\S \S 180$-184; necessidade, $\S \S 185-202$; proporcionalidade em sentido estrito, $\S$ 203-205).

Ao final, a Corte reconheceu que o Estado "no violó, en perjuicio del señor Jorge Castañeda Gutman, el derecho político a ser elegido reconocido en el artículo 23.1.b de la Convención Americana sobre Derechos Humanos [...]" (CorteIDH, 2008, § 251.3 , p. 67).

Apesar de a Corte ter afastado a violação ao art. 23.2 da Convenção no caso em análise, ela fixou duas importantes diretrizes interpretativas que gozam de especial projeção para os propósitos deste artigo: (i) os direitos políticos são essenciais à democracia e impõem uma série de exigências de proteção tendo em vista o dever de assegurar a oportunidade aos cidadãos de participarem efetivamente da formação da vontade política do Estado, e (ii) no exercício do dever de regulamentação dos sistemas eleitorais, o Estado pode fixar condições não previstas no art. 23.2 para viabilizar o exercício ao direito de votar e ser votado, no entanto, a atividade de conformação do Estado está sujeita ao controle de compatibilidade a ser empreendido pelas instituições do SIDH.

\subsection{AnÁlise do caso López Mendoza vs. Venezuela (1º De SETEMBro de 2011).}

A SANÇão DE INABILITAÇÃo (INELEGIBIDADE) DEVE SER PROFERIDA POR ÓRGÃo JUDiCIAL

O caso López Mendoza vs.Venezuela foi julgado em 1 de setembro de 2011 e discute exatamente os limites impostos aos Estados no que diz respeito às restrições aos direitos políticos passivos (direito de ser votado). A questão de direito enfrentada analisa se é facultado aos Estados definir novas causas de restrições não previstas no art. 23.2 da Convenção Americana. Analisemos, pois, os fatos submetidos à apreciação da CorteIDH.

O Sr. Leopoldo López Mendoza foi eleito em 2000 (e reeleito em 2004) prefeito do Município de Chacao, unidade integrante do Distrito Metropolitano de Caracas. No final do segundo mandato, ele pretendia candidatar-se à Alcadía Mayor de Caracas (órgão político-administrativo que congrega a região metropolitana de Caracas), no entanto, foi impedido de se candidatar por força da imposição de duas sanções de inabilitação (sanções de inelegibilidade) decretadas pelo Controlador Geral da República $^{3}$ : a primeira, decorrente de processo que apurou a existência de conflito de interesses quando, antes de ser prefeito, trabalhava na empresa Petróleos de Venezuela S.A. (PDVSA) e como voluntário em uma organização não governamental que recebeu subvenções sociais da estatal venezuelana; e a segunda, decorrente da aplicação de multa por ter ele, no exercício do mandato de Prefeito Municipal, aplicado verbas orçamentárias em desacordo com a finalidade legal.

Em razão do primeiro procedimento, o órgão administrativo aplicou-lhe sanção pecuniária (multa) equivalente a US\$ 647,50 e, posteriormente, seguindo o rito procedimental local, foi editada Resolução de inabilitação para o exercício de funções 
públicas por 3 (três) anos. Em razão do segundo procedimento, o órgão administrativo aplicou-lhe multa (equivalente a US\$ 4.239,58) e, em seguida, por entender que a conduta era grave e que seria o caso de reincidência, editou Resolução de inabilitação para o exercício de funções públicas pelo período de 6 (seis) anos. Ambas decisões foram confirmadas pela Sala Constitucional do Tribunal Supremo de Justiça que afastou os recursos de nulidade requeridos para desconstituir estas decisões. Em virtude destas sanções, o Sr. Leonardo López Mendoza não pôde se inscrever para a postulação do cargo de Prefeito do Distrito Metropolitano de Caracas perante a Junta Eleitoral do referido distrito.

Ao propor a demanda perante a Corte, a ComissãoIDH postulou que fosse reconhecida a violação ao direito de ser eleito (ofensa ao art. 23.1.b e 23.2 da Convenção); a existência de ofensa às garantias judiciais nos procedimentos administrativos desenvolvidos; e, ainda, a existência do dever de adotar disposições de direito interno para salvaguardar tais garantias convencionais. Neste trabalho, ater-se-á mais detidamente ao primeiro aspecto.

$\mathrm{Na}$ análise do caso, a questão foi delimitada pela Corte nos seguintes termos:

100. El punto central del presente caso radica en las sanciones de inhabilitación impuestas al senor López Mendoza por decisión de un órgano administrativo en aplicación del artículo 105 de la LOCGRSNCF, que le impidieron registrar su candidatura para cargos de elección popular. Luego de resenar los alegatos de las partes, la Corte determinará si dichas sanciones y sus efectos sobre la presunta víctima son o no compatibles con la Convención Americana. (CorteIDH, 2011, § 100, p. 43).

Dentre as inúmeras razões apresentadas pelo Estado contra a alegada incompatibilidade, destacam-se os seguintes argumentos:

(i) o art. 105 da lei nacional foi promulgado em estrita observância da constituição venezuelana, razão pela qual eventual antinomia dele com o art. 23.2 da Convenção não resulta em automática prevalência desse em relação à Constituição da Venezuela;

(ii) a sanção de inabilitação imposta pelo Controlador Geral não é de natureza política porque não implica em uma suspensão de todos os direitos políticos, mas somente o inabilita para exercer determinadas funções públicas, por determinado período;

(iii) inúmeros outros países sancionaram normas semelhantes no contexto de luta contra a corrupção; 
(iv) a sanção de inabilitação que impõe o Controlador tem como objetivo a luta contra a corrupção e a proteção do erário público, o qual corresponde a um interesse público imperativo.

Em relação ao primeiro e terceiro argumentos, pronunciou-se à Corte:

104. [...] No corresponde, en cambio, que la Corte se pronuncie sobre la interpretación del derecho interno venezolano y, en particular, sobre la compatibilidad o incompatibilidad del artículo 105 de la LOCGRSNCF con la Constitución de Venezuela. Asimismo, la Corte considera que para decidir el presente caso no es necesario realizar un pronunciamiento respecto a los alegatos de derecho comparado presentados por el Estado. (CorteIDH, 2011, § 104, p. 44)

Em relação à situação analisada, a Corte entendeu que se trata de hipótese de aplicação direta do art. 23 da Convenção, "porque se trata de sanciones que impusieran una clara restricción a uno de los derechos políticos reconocidos por el párrafo 1 de dicho artículo, sin ajustarse a los requisitos aplicables de conformidad con el párrafo 2 del mismo." (CorteIDH, 2011, § 105, p. 44-45).

O raciocínio empreendido pela Corte foi linear e afastou de maneira categórica as duas oposições feitas pelo Estado, in verbis:

106. El artículo 23.1 de la Convención establece que todos los ciudadanos deben gozar de los siguientes derechos y oportunidades, los cuales deben ser garantizados por el Estado en condiciones de igualdad: i) a la participación en la dirección de los asuntos públicos, directamente o por representantes libremente elegidos; ii) a votar y a ser elegido en elecciones periódicas auténticas, realizadas por sufragio universal e igual y por voto secreto que garantice la libre expresión de los electores, y iii) a acceder a las funciones públicas de su país.

107. El artículo 23.2 de la Convención determina cuáles son las causales que permiten restringir los derechos reconocidos en el artículo 23.1, así como, en su caso, los requisitos que deben cumplirse para que proceda tal restricción. En el presente caso, que se refiere a una restricción impuesta por vía de sanción, debería tratarse de una "condena, por juez competente, en proceso penal". Ninguno de esos requisitos se ha cumplido, pues el órgano que impuso dichas sanciones no era un "juez competente", no hubo "condena" y las sanciones no se aplicaron como resultado de un "proceso penal”, en el que tendrían que haberse respetado las garantías judiciales consagradas en el artículo 8 de la Convención Americana. 
108. La Corte estima pertinente reiterar que "el ejercicio efectivo de los derechos políticos constituye un fin en sí mismo y, a la vez, un medio fundamental que las sociedades democráticas tienen para garantizar los demás derechos humanos previstos en la Convención y que sus titulares, es decir, los ciudadanos, no sólo deben gozar de derechos, sino también de "oportunidades". Este último término implica la obligación de garantizar con medidas positivas que toda persona que formalmente sea titular de derechos políticos tenga la oportunidad real para ejercerlos. En el presente caso, si bien el senor López Mendoza ha podido ejercer otros derechos políticos (supra párr. 94), está plenamente probado que se le ha privado del sufragio pasivo, es decir, del derecho a ser elegido.

109. En virtud de lo que antecede, la Corte determina que el Estado violó los artículos 23.1.b y 23.2 en relación con el artículo 1.1 de la Convención Americana, en perjuicio del senor Leopoldo López Mendoza. (destaque dos autores) (CorteIDH, 2011, §§ 106-109, p. 45)

Simples assim. A opinião majoritária da Corte nem sequer considerou os argumentos do Estado no tocante à existência de um esforço de combate à corrupção. Tratou a Corte de reconhecer que o dispositivo convencional impõe uma obrigação clara de que os Estados só poderiam restringir os direitos políticos fundamentais (de ser eleito, no caso) como resultado da prática de um comportamento tido por ilícito (inelegibilidade cominada) se, e somente se, este provimento judicial ostentasse os três elementos previstos na parte final do art. 23.2: ter sido emitido por juiz competente, ter havido uma condenação (com trânsito em julgado) e ter sido proferido em um processo penal.

Por sua vez, empreendendo autêntico controle judicial de convencionalidade, a CorteIDH analisou a compatibilidade do direito interno (art. 105 da Lei Nacional venezuelana) em face da Convenção nos seguintes termos:

206. En consecuencia, al no cumplir con el requisito de previsibilidad y, ademas, teniendo en cuenta lo senalado en el sentido que el articulo 105 de la LOCGRSNCF permite la restriccion del derecho a ser elegido por una autoridad que no es juez penal (supra parrs. 107 y 108), la Corte concluye en el presente caso se vulneraron los articulos 8.1, 23.1.b y 23.2, en relacion con los articulos 1.1 y 2 de la Convencion Americana. (CorteIDH, 2011, §§ 206, p. 73)

Em relação ao ponto específico - sobre a interpretação a ser atribuída ao art. 23.2 e sobre a possibilidade de que a mesma pudesse ser flexibilizada pelas jurisdições de outros Estados -, houve um embate vigoroso entre os juízes Diego García-Sayán e 
Eduardo Vio Grossi, o que transparece nos votos concorrentes apresentados por ambos, em acréscimo à opinião majoritária da Corte.

O juiz Diego García-Sayán insurgiu-se contra a interpretação literal emprestada pela maioria ao art. 23.2 da Convenção Americana. Em seu voto, propôs uma interpretação compreensiva do dispositivo de forma a admitir a possibilidade de que o Estado impusesse outras restrições, sempre pela via judicial (é digno de nota), mediante decisões provenientes de outras instâncias de responsabilização (civil, eleitoral, administrativa, por exemplo).

Por seu turno, o juiz Eduardo Vio Grossi foi contundente em afirmar que o dispositivo convencional

[...] resulta claro, sencillo y categórico, particularmente en lo que en autos interesa, a saber, que "el ejercicio de los derechos y oportunidades a que se refiere" el numeral 1 del mismo, especialmente el concerniente al derecho de "ser elegido (...)", puede ser reglamentado "exclusivamente" por, entre otras causales, "condena, por juez competente, en proceso penal”. (CorteIDH, 2011, Voto

Concorrente do juiz Eduardo Vio Grossi, p. 1)

Ato contínuo, o juiz Eduardo Vio Grossi empreendeu esforço em desconstruir as razões apresentadas pelo seu colega aduzindo ser equivocada a referência feita às técnicas de interpretação de direito internacional no processo de compreensão da expressão "exclusivamente" (do art. 23.2 da Convenção). Afinal de contas, "la Sentencia ha procedido fijando el sentido y alcance de este ultimo segun su unica alternativa de aplicación posible”.

Vale registrar, por oportuno, o entendimento fixado por Nogueira Alcalá, que atuou no caso como perito e afasta o argumento de que a Lei Nacional é inconvencional per si, mas acusa como inadequado o pronunciamento feito pelos órgãos administrativo e judicial venezuelanos. Sustenta o constitucionalista chileno, com bastante propriedade, que a sanção administrativa acessória de inabilitação ao exercício de cargos públicos por tempo determinado

[...] debería aplicarse sólo a los cargos que tienen su origen en un acto administrativo de nombramiento por alguno de los órganos del Estado, pero no debería aplicarse ni podría constitucionalmente aplicarse para los funcionarios que fueren electos mediante sufragio. En esta última hipótesis, es el pueblo quien elige, en ejercicio de la soberanía popular, de acuerdo al artículo $5^{\circ}$ de la Constitución, no pudiendo un órgano administrativo contralor, conforme a la Constitución, limitarle al pueblo el ejercicio de su poder soberano. (NOGUEIRA ALCALÁ, 2011, p. 361-362) 
De todo o exposto, pode-se concluir que, em consonância com o precedente analisado, a Corte Interamericana de Direitos Humanos entende que: (i) o direito público de ser eleito (previsto no art. 23.1.b da Convenção) é de índole fundamental e só pode ser restringido em estrita observância às condicionantes definidas no art. 23.2 da Convenção; (ii) em se tratando de suspensão de direitos políticos decorrentes da aplicação de uma sanção, para que a mesma seja válida, faz-se imprescindível que tenha sido proveniente de um juiz competente, que tenha havido condenação definitiva e que tenha sido proferida em um processo penal.

\subsection{Natureza JURídica da SENTENÇa interamericana. EFicÁcia erga omNes dos PRONUNCIAMENTOS DA CORTE (RES INTERPRETATA)}

A CorteIDH considera as normas internas - atos administrativos, leis, constituição, decisões judiciais - como "meros fatos", expressões de vontade dos Estados, e procede ao cotejo destes fatos com a Convenção, buscando proteger a eficácia do objeto e o fim do instrumento internacional (LONDOÑO LÁZARO, 2010, p. 805-806). $\mathrm{E}$, ante eventual incompatibilidade, a CorteIDH declara a responsabilidade internacional do Estado por descumprimento da Convenção e condena-o a adequar o ordenamento interno à Convenção (REY CANTOR, 2009). Trata-se, portanto, de um exame de adequação de uma conduta do Estado com uma prescrição internacional estabelecida (LONDOÑO LÁZARO, 2010, p. 796-798). Nesse contexto, são irrelevantes justificativas internas - ainda que baseadas nas próprias Constituições - sobre a existência de esforço nacional de combate à corrupção, ou ainda, a observância de outros princípios de interesse público a justificar as restrições legais.

É bem verdade, como adverte Eduardo Ferrer Mac-Gregor (2013, p. 655), que a eficácia vinculante (res judicata) só se opera em relação ao Estado-Parte acionado pela Corte (no caso, o Estado venezuelano), de forma que uma corte nacional não pode "invalidar una decisión de una corte internacional y [...] negar la existencia de una violación al derecho internacional ya declarada a nivel internacional en un caso concreto".

Isso não significa esvaziar os efeitos da decisão em relação aos demais países signatários. Muito pelo contrário, defende Eduardo Ferrer MacGregor que a sentença interamericana adquire ainda a eficácia "de manera objetiva e indirecta hacia todos los Estados Parte en la Convención Americana”, já que:

33. [...] se produce una eficacia erga omnes hacia todos los Estados Parte de la Convencion, en la medida en que todas las autoridades nacionales quedan vinculadas a la efectividad convencional y, consecuentemente, al criterio interpretativo establecido por la Corte IDH, en tanto estandar minimo de efectividad de la norma convencional, derivada de la obligacion de los Estados de respeto, garantia y adecuacion (normativa 
e interpretativa) que establecen los articulos 1o y 2o de la Convencion Americana; y de ahi la logica de que la sentencia sea notificada no solo "a las partes en el caso" sino tambien "transmitido a los Estados partes en la Convencion" en terminos del articulo 69 del Pacto de San Jose. (destaque dos autores) (FERRER MAC-GREGOR, 2013, p. 657).

O fundamento, pois, resulta de um compromisso compartilhado de se conferir efetividade regional a esses padrões reconhecidos como mínimos aceitáveis. Caso uma interpretação nacional não se ajuste a este padrão mínimo, "existe un incumplimiento de la obligacion de 'adecuacion' previsto en el articulo $2^{\circ}$ del Pacto de San Jose, es decir, al existir una inadecuada actuacion interna con la Convencion" (FERRER MACGREGOR, 2013, p. 666).

Nesse contexto, não é dado aos Estados a faculdade de se escusar a cumprir tais padrões mínimos. Extrai-se da boa-fé contratual, que os Estados devam conferir aplicabilidade a dispositivo de sua ordem interna que seja mais protetivo à garantia convencional nos termos fixados pela diretriz interpretativa da Corte.

Em ambos os precedentes analisados, a par do reconhecimento do direito à reparação econômica pelo dano experimentado pela vítima, a Corte determinou aos Estados que realizassem, em um prazo razoável, a adequação de seus ordenamentos jurídicos nacionais à obrigação convencional tida por violada. Dessa forma, a Corte estabeleceu que fossem removidos os óbices legislativos e/ou que fosse adequada a norma processual doméstica a fim de que as diretrizes fixadas fossem devidamente incorporadas à legislação nacional.

A análise de conformação entre o sistema brasileiro de inelegibilidades (à luz da interpretação veiculada pelo Supremo Tribunal Federal) e os standards mínimos de proteção do direito político de ser votado (exercício do direito de sufrágio passivo) é o que será objeto de apreciação específica na próxima seção.

\section{Controle de Convencionalidade e as possiblidades de Adequação DO ORDENAMENTO PÁTRIO AOS TERMOS DA CONVENÇÃO}

\section{I Controle de Convencionalidade:}

CONCEITO, HISTÓRICO, FUNDAMENTOS E OPERACIONALIZAÇÃO

O controle judicial de convencionalidade surge no âmbito do sistema regional de proteção de direitos humanos americano "como uma ferramenta sumamente eficaz para o respeito, a garantia e a efetivação dos direitos descritos no Pacto [de San José da Costa Rica]” (SAGÜES, 2010, p. 118), resultado da construção pretoriana da Corte Interamericana. Por esse controle, "as normas locais passam a ter a compatibilidade aferida diante das normas internacionais” (RAMOS, 2005, p. 86). 
À semelhança da contraparte nacional (o controle de constitucionalidade), o controle judicial de convencionalidade afirma-se discursivamente como meio de salvaguarda dos direitos humanos previstos em normas plasmadas em documentos internacionais. Ademais, o recurso a este mecanismo igualmente é justificado a partir do recurso aos postulados da integridade sistêmica (unidade, coerência e completude dos ordenamentos jurídicos), como se depreende da função de preservação da integridade da Convenção Americana, assinalada por Alberto Lucchetti (2008), ou a preocupação em salvaguarda de uma suposta "aplicação harmônica do direito vigente" genericamente preconizada por Susana Albanese (2008, p. 15).

A noção de confrontação e de compatibilidade vertical fica evidente na definição analítica de Rey Cantor (2009, p. 8-9), para quem:

[...] (t)rata-se de um exame de confrontação normativa (material) do direito interno com a norma internacional, sobre alguns fatos - ação ou omissão internacionalmente ilícitos. A confrontação é uma técnica jurídica que se denomina controle, e tem por objeto "assegurar e fazer efetiva a supremacia" da Convenção Americana.

Apesar de a Corte ter cunhado a expressão "controle de convencionalidade", trata-se, de fato, de um autêntico "controle judicial de convencionalidade", uma vez que o dever de exercê-lo é endereçado aos juízes - ao Poder Judiciário -, que devem realizá-lo quando o legislador se esquivar de sua tarefa de suprimir ou de não editar normas contrárias à Convenção (GALVIS; SALAZAR, 2007; LUCCHETTI, 2008). Enfim, sinteticamente, o controle judicial de convencionalidade preconizado pela Corte Interamericana afigura-se como "um mecanismo jurídico pelo qual os juízes invalidam normas de hierarquia inferior à convenção que não tenham sido ditadas em conformidade com ela, tendo em conta não somente a Convenção mesma, mas igualmente a interpretação que a ela dá a Corte Interamericana" (SCHEPIS, 2009, p. 7).

No controle judicial de convencionalidade, operam tanto os juízes nacionais quanto a CorteIDH. Em razão disso, a doutrina distingue duas classes de controle de convencionalidade, a saber: (a) controle de convencionalidade em sede interna; e (b) controle de convencionalidade em sede internacional, respectivamente (REY CANTOR, 2009; SAGÜES, 2010).

Assim, os juízes nacionais encontram-se obrigados a rechaçar a norma interna "inconvencional" ex officio, independentemente de requerimento das partes (SAGÜES, 2010). Afirmar este dever de declaração ex officio, como assinala Hitters (2009), implica conferir preponderância ao princípio do iura novit curia em detrimento do princípio da congruência (comum no direito processual interno de adstrição do magistrado às alegações das partes). 
Havendo observância dos ditames convencionais e das pautas interpretativas fixadas pela Corte pelos juízes internos, não há necessidade de acudir ao sistema internacional (REY CANTOR, 2009). Em suma, o controle de convencionalidade é realizado previamente pela instância doméstica, donde a intervenção da Corte Interamericana só se realizará necessária em face da inoperância ou ineficácia dos órgãos nacionais (HITTERS, 2008, p. 135-136).

A título de conclusões parciais, pode-se perceber que, de acordo com a construção pretoriana da Corte Interamericana de Direitos Humanos, o exercício do controle de convencionalidade incumbe primariamente aos próprios juízes nacionais e, de forma subsidiária, às instâncias de controle supranacional. Desta feita, o controle de convencionalidade a cargo da Corte (controle de convencionalidade em sede internacional) constitui sua atividade por excelência, sua razão de existir, que o realiza desde sua instituição, ao confrontar os fatos que traduzem a conduta dos Estados-Partes com as normas convencionais.

\subsection{Sistema de inelegibilidades INFraconstitucionais E a ANÁlise de compatibilidade com a Convenção Americana de Direitos Humanos}

Fixadas as premissas teóricas, convém empreender um primeiro esforço de confrontação entre o sistema brasileiro de inelegibilidades e a garantia convencional de exercer os direitos políticos passivos (em especial, o de ser eleito).

De início, faz-se importante reiterar os standards interpretativos emanados dos casos analisados: (i) os direitos políticos são essenciais à democracia e impõem uma série de exigências de proteção tendo em vista o dever de assegurar ampla oportunidade aos cidadãos de participarem efetivamente da formação da vontade política do Estado (caso Castañeda Gutman vs. Estados Unidos Mexicanos); (ii) no exercício do dever de regulamentação dos sistemas eleitorais, o Estado pode fixar condições não previstas no art. 23.2, a fim de viabilizar o exercício concreto do direito de votar e ser votado (no sentido de exercício de condições de habilitação); no entanto, esta atividade não é livre e sujeita-se ao controle de proibição de excesso do princípio da proporcionalidade (caso Castañeda Gutman vs. Estados Unidos Mexicanos); (iii) o direito de ser eleito (23.1.b) é direito público subjetivo e só pode ser restringido em estrita observância às causas definidas no art. 23.2 (caso López Mendoza vs. Venezuela); (iv) em se tratando de suspensão de direitos políticos em face da aplicação de uma sanção, é imprescindível que esta repreensão advenha de juiz competente, revista-se de definitividade e tenha sido proferida em processo penal (caso López Mendoza vs.Venezuela).

A simples enunciação dessas premissas já são per si reveladoras. As inelegibilidades precisam ser tratadas desde uma perspectiva muito distinta daquela que, até então, vem dominando os tribunais brasileiros. Diferentemente do discurso de matiz moralizante e excludente que vige entre nós, a lógica que preside a matéria no âmbito do sistema interamericano é a de que os Estados devem ampliar, ao máximo, os legitimados para 
se lançarem aos pleitos eleitorais (garantia de ampla oportunidade de participação em pleitos periódicos e autênticos).

Portanto, não são adequadas as interpretações que subtraem a feição de garantia fundamental aos direitos políticos passivos. O direito a lançar-se como candidato nas eleições é tão fundamental quanto o direito de votar. São duas facetas indissociáveis do jus sufraggi e que gozam de idêntica dignidade. Não há que se confrontar o direito de ser votado ao direito à democracia como bens em contraposição (como consigna o Supremo Tribunal Federal na ADI n. 4.578).

Desta feita, a restrição do direito público subjetivo de um candidato não afeta somente ao seu patrimônio jurídico, mas atinge a toda a coletividade que vê reduzida a sua liberdade de escolha democrática. Trata-se, pois, de uma garantia institucional que transcende (e excede) ao âmbito de proteção dos indivíduos que são afetados pela restrição do exercício de um direito fundamental seu. Trata-se de uma perspectiva muito diferente daquela que foi subscrita na decisão do Supremo Tribunal Federal.

Ainda há de se chamar atenção à (falta de) legitimidade do uso empreendido pelo Supremo Tribunal Federal no tocante à proteção da moralidade administrativa e à defesa das instituições democráticas contra o abuso de direito (extraídos do art. 14, $\S 9^{\circ}$ da CF). Os bens contrapostos no juízo de proporcionalidade aplicado pela Corte brasileira adotam parâmetros (e pontos de partida) bem diferenciados daqueles empreendidos pela CorteIDH. Não é possível opor o direito político fundamental de ser eleito à democracia, como quer o STF, pois a sua promoção ao máximo está intimamente conectada ao próprio exercício da democracia.

E o que se revela sintomático na jurisprudência da CorteIDH é que o argumento de combate à corrupção, de compatibilidade com o texto constitucional nacional e as necessidades imperiosas de salvaguarda do interesse público, nem sequer devem ser considerados quando se estiver diante de ofensa direta à garantia convencional fundamental. Nessas hipóteses - de restrições ao exercício do direito de ser eleito -, a interpretação deve se dar em estrita consonância com as condicionantes previstas na própria Convenção. Em outras palavras, em se tratando de lei que restringe o direito de ser eleito, não há outra alternativa hermenêutica à Corte que não a estrita observância das regras consignadas no art. 23.2. Portanto, quando se pretende fazer a análise de conformação entre a legislação brasileira sobre inelegibilidades fazse imprescindível que as regras brasileiras sejam confrontadas com as causas definidas neste dispositivo convencional.

Na primeira seção deste artigo, foram listados grupos de causas de inelegibilidades, grupos esses que serão a seguir reproduzidos à medida que forem analisados neste artigo.

Para que se faça a análise de compatibilidade, faz-se necessário empreender um primeiro esforço de diferenciação entre aquelas inelegibilidades resultantes da decisão soberana do Estado de relativa liberdade de conformação do sistema eleitoral nacional, 
e o regime das inelegibilidades que seriam resultantes de cominações fixadas pelo Estado em face de comportamentos tidos como incompatíveis com a possibilidade do exercício do direito político de ser eleito. E, ato contínuo, impõe-se fazer uma análise sobre o preenchimento (ou não) dos requisitos fixados pelo art. 23.2 em relação a estas últimas hipóteses de inelegibilidades cominadas.

Pois bem, o primeiro grupo de inelegibilidades - aquele que não goza do direito político passivo tout court (inc. I, "a" ${ }^{4}$ ) - diz respeito às chamadas inelegibilidades inatas, ou seja, resultante daquelas hipóteses em que os cidadãos não possuem os requisitos definidos pela legislação para serem reconhecidos como titulares de direitos políticos passivos (os inalistáveis) e, ainda, aquele grupo de cidadãos que, a par de ostentarem o status de direito político ativo, em face do não preenchimento de uma condição mínima (ser alfabetizado), não lhe é conferido o direito político passivo (de ser eleito).

Em relação ao primeiro elemento (a alistabilidade), uma adequada análise de compatibilidade da ordem brasileira ao sistema internacional exigiria que fosse feito análise pormenorizada das condições de alistabilidade e, ainda, das condições de elegibilidade definidas pela legislação. Essa análise seria importante para verificar se as hipóteses definidas na legislação seriam compatíveis com as restrições autorizadas pela Convenção ("idade, nacionalidade, residência, idioma, instrução, capacidade civil ou mental”). E, adiante, tendo sido identificada condição legal que não guarde relação direta com estas hipóteses, nos termos do que foi fixado no caso Castañeda Gutman vs. Estados Unidos Mexicanos, caberia fazer um acurado escrutínio sobre a norma nacional a fim de aferir se a restrição imposta passa pelo teste de legalidade e de proporcionalidade. Tal análise, no entanto, excede os limites deste trabalho.

Em relação ao segundo elemento (a condição de analfabeto), esta restrição encontra expressa previsão no dispositivo convencional como causa a justificar limite ao exercício dos direitos políticos previstos no art. 23.1.b. O texto convencional expressamente consigna a "instrução" como hipótese a autorizar a edição de norma restritiva de direitos, razão pela qual a norma passaria pelo teste de convencionalidade.

Para que seja feita a análise de compatibilidade em relação aos demais grupos, faz-se importante fazer uma rápida análise sobre a natureza das inelegibilidades ali definidas. Isto é assim porque, sendo elas tidas como inelegibilidades cominadas, as mesmas sujeitam-se ao escrutínio estrito fixado na parte final do art. 23.2 da Convenção.

Quando se lançou a proposta de alteração legislativa que resultou na LC n. 135/2010, o primeiro esforço de desconstrução empreendido dizia respeito à tentativa de desvencilhar a natureza de sanção destas hipóteses de inelegibilidade, a fim de tratá-la como condição objetiva de elegibilidade. Este esforço resultaria de uma

[...] relevante mudança de paradigmas no direito eleitoral pátrio, assegurando a plena efetividade do disposto no $\S 9^{\circ}$ do art. 14 da 
Constituição Federal e instituindo importantes conquistas para o saneamento dos costumes políticos no país, protegendo a moralidade e a probidade administrativa no exercício de mandatos, considerando a vida pregressa do candidato. (COELHO, 2010, p. 55)

Em sentido diametralmente oposto, diversos autores reiteraram a natureza sancionatória desta espécie de inelegibilidade, pois elas resultariam da violação de um bem jurídico protegido. Nessa toada, tais restrições não se materializariam em face de um

[...] simples impedimento ao exercício do jus honorum, configura-se o enquadramento na tipologia subsuntiva em uma pena, em que mesmo o cidadãos se afastando do fato jurídico descrito na lei, ainda assim ele estará inelegível pelo lapso temporal determinado na reprimenda.

(AGRA, 2012, p. 22)

Como dito anteriormente, a questão não deixou de ser enfrentada pelo Supremo Tribunal Federal. Muito pelo contrário, a condição sine qua non para que aquela Corte reconhecesse a integral constitucionalidade do diploma consistia justamente no expresso afastamento da noção de sanção de inelegibilidade, a fim de reconceituá-la como "causa de inelegibilidade", em face da sua condição objetiva a ser aferível por ocasião do pedido de registro de candidatura. Sem a definição dessa premissa, seria difícil sustentar a constitucionalidade do diploma no tocante às alegadas violações à presunção de inocência e à irretroatividade da lei (decorrente da ampliação do tempo de impedimento e da inclusão de novas hipóteses).

Em certo sentido, a questão foi enfrentada pela Corte Interamericana no caso López Mendoza vs.Venezuela, quando afastou o argumento de que a sanção aplicada não se revestia de natureza política, porque o mesmo continuava no exercício dos demais direitos políticos. Este argumento igualmente foi utilizado na decisão do Supremo Tribunal Federal; no entanto, a Corte Interamericana assentou que este elemento não era suficiente para descaracterizar a natureza sancionatória da norma regulamentadora.

A restrição do direito político (mesmo que adstrita ao direito político passivo) configura, para os efeitos da incidência do art. 23.2, restrição de natureza sancionatória, o que, para a CorteIDH, só pode ser considerado como compatível com a Convenção Americana se tiver sido resultado de procedimento definido na parte final do mencionado dispositivo.

Inarredável, pois, o caráter sancionatório definido pelas hipóteses de inelegibilidade previstas nas alíneas "b" a "q". Sendo assim, devem-se aplicar os standards interpretativos extraídos diretamente da literalidade do texto convencional: (iv) é imprescindível que esta repreensão advenha de juiz competente, revista-se de definitividade e tenha sido proferida em processo penal (caso López Mendoza vs.Venezuela). 
Sem sequer analisar detidamente outros critérios para aferição de compatibilidade das hipóteses legais brasileiras em relação à Convenção, à evidência as hipóteses que foram agrupadas no segundo grupo (agentes políticos cassados ou que tenham renunciado, hipóteses das alíneas "b", 5 "c"6 e "k"7) e no quarto grupo (efeitos indiretos de sanções administrativas, hipóteses das alíneas "f", "g" 9 "i”, 10 “m”, 11 “o"12 e "q"13), não preenchem o primeiro requisito, qual seja, ter sido a sanção de inelegibilidade resultante da imposição de um juiz competente. Em qualquer contexto em que se leve a sério os direitos políticos fundamentais, não se pode consentir com a possibilidade de que sanções impostas por autoridades administrativas (inclusive corporações) possam ter tão grave efeito secundário: o banimento da vida pública de cidadãos por inadmissíveis 8 (oito) anos.

Nestas hipóteses, a simples confrontação já permite que se exclua, de plano, a possibilidade de reconhecer como convencional esta norma e, por conseguinte, admitir como compatível com o regime de proteções da Convenção afastamentos determinados com base nessas premissas.

Isso posto, convém analisar o terceiro grupo de inelegibilidades elencado como resultantes de decisão judicial. Neste universo, temos um conjunto de hipóteses que, presentes, atraem como consequência a inelegibilidade daquele que foi sancionado no âmbito dos procedimentos judiciais em questão.

Pois bem, as inelegibilidades resultantes de condenações em processos eleitorais (alíneas "d”, 14“j”, 15 “n”16 e "p"17) e processos de natureza civil (alíneas "h"18 e "l"19) não se mostram compatíveis com a garantia convencional insculpida na parte final do art. 23.2. O óbice revela-se intransponível. A referência constante no dispositivo constitucional concernente à "vida pregressa do candidato" e à "normalidade e legitimidade das eleições" não é suficiente para conferir validade às hipóteses de inelegibilidade que impõem restrições outras que não aquelas definidas no art. 23.2. O dispositivo convencional excetua, tão somente, as hipóteses em que ocorre sanção decorrente de sentença em processo penal. E nada mais.

Por fim, quanto às hipóteses decorrentes de condenações criminais (alínea "e"20), os efeitos da inelegibilidade só podem advir de decisão que já tenha transitado em julgado.

Revestindo-se a inelegibilidade de inegável natureza sancionatória, quando a Corte condiciona que as restrições aos direitos políticos só podem decorrer de sentença em processo penal, acaba por estender à interpretação do regime de proteção o conjunto de precedentes da Corte no tocante às garantias processuais penais igualmente insculpidas na Convenção. Desta forma, a inovação levada a termo pela Lei Complementar n. 135/2010, que passou a reconhecer que os efeitos seriam decorrentes de "decisão transitada em julgado ou proferida por órgão judicial colegiado”, viola frontalmente o princípio da presunção de inocência (por força da vinculação determinada pelo art. 23.2 da Convenção). 
O princípio da presunção de inocência é considerado como sendo de tratamento, porque orienta que o acusado seja tratado como inocente até que haja uma sentença condenatória transitada em julgado. Isso impõe diversas limitações à forma de atuação do Estado para com o indivíduo denunciado. (CAMARGO, 2005, p. 57). Na Convenção Americana de Direitos Humanos, em seu bojo de direitos e garantias, encontra-se protegido o princípio da presunção de inocência. $O$ art. 8.2 da Convenção dispõe que: "toda pessoa acusada de um delito tem direito a que se presuma sua inocência enquanto não se comprove legalmente sua culpa".

Extrai-se desse estado de inocência, reconhecido pela Corte Interamericana (e pelos tribunais domésticos), que a única "mitigação" ao princípio da presunção de inocência derivaria das hipóteses de prisão preventiva, pois ali se trata de proteção do processo, não de antecipação de qualquer efeito condenatório, já que qualquer antecipação importa em violação à garantia do art. 8.2 do Texto Convencional. Razão pela qual a alteração legislativa que antecipa os efeitos da condenação criminal para fins de inelegibilidade revela-se de todo incompatível com a Convenção Americana de Direitos Humanos, bem como com a jurisprudência da CorteIDH, seja no que se refere às inelegibilidades, seja na forma de compreensão da presunção de inocência.

\section{CONSIDERAÇÕES FINAIS}

Desde a edição da Lei da Ficha Limpa (LC n. 135/2010), experimenta-se um processo de exacerbação do papel a ser assumido pela Justiça Eleitoral como instância de controle da legitimidade dos pleitos eleitorais. De instância arbitral de contenção dos excessos, a Justiça Eleitoral assume um papel de instância reformadora da política (e dos vícios por si detectados). Ao agir desta forma, com o escopo de zelar pela legitimidade do pleito, a pretensão de depuração moral dos candidatos a ser controlada pelo Judiciário (nas impugnações do registro de candidatura) acaba por minar, em última instância, a própria legitimidade democrática do sistema de representação política.

$\mathrm{O}$ que se pretendeu neste artigo foi confrontar as hipóteses de inelegibilidade infraconstitucional (definidas no art. $1^{\circ}$ da LC n. 64/90) com a garantia convencional definida no art. 23.1.b e art. 23.2 da Convenção Americana. Para tanto, buscou-se confrontar o direito doméstico com os standards interpretativos emanados da Corte Interamericana de Direitos Humanos a partir dos quais se pode identificar o conteúdo e o alcance da garantia insculpida na Convenção.

A Corte Interamericana de Direitos Humanos possui dois precedentes bastante emblemáticos em relação ao alcance dos direitos políticos passivos e o seu âmbito de proteção em face do Estado. O primeiro (o caso Castañeda Gutman vs. Estados Unidos Mexicanos, de 6 de agosto de 2008) em que se discutiu a possibilidade de se assegurar a candidatura independente à Presidência como decorrência direta da garantia convencional prevista no art. 23.1.b; e o segundo (o caso López Mendoza vs.Venezuela, de 11 
de setembro de 2011) em que se discutiu especificamente a aplicação de sanções de inabilitação em processos administrativos (apuração de sanção disciplinar e regularidade na execução orçamentária), afirmando que esta hipótese de suspensão de direitos políticos não estaria autorizada pelo art. 23.2 da Convenção.

Destes precedentes, especificamente em relação a essas garantias convencionais, podem ser identificados os seguintes standards interpretativos: (i) os direitos políticos são essenciais à democracia e impõem uma série de exigências de proteção, tendo em vista o dever de assegurar ampla oportunidade aos cidadãos de participarem efetivamente da formação da vontade política do Estado; (ii) no exercício do dever de regulamentação dos sistemas eleitorais, o Estado pode fixar condições não previstas no art. 23.2, a fim de viabilizar o exercício concreto do direito de votar e ser votado (no sentido de exercício de condições de habilitação); no entanto, esta atividade não é livre e sujeita-se ao controle de proibição de excesso do princípio da proporcionalidade; (iii) o direito de ser eleito (23.1.b) é direito público subjetivo e só pode ser restringido em estrita observância às causas definidas no art. 23.2; e, (iv) em se tratando de suspensão de direitos políticos em face da aplicação de uma sanção, é imprescindível que esta repreensão advenha de juiz competente, revista-se de definitividade e tenha sido proferida em processo penal.

Apesar desses precedentes não terem emanados de processos contra o Brasil, os mesmos gozam de eficácia erga omnes. Em outras palavras, espera-se que os demais Estados signatários possam incorporar esses standards como forma de reforço recíproco do conjunto de garantias convencionais no continente regional. Esta eficácia expansiva é tratada pela Corte como res interpretata e tem sido utilizada pelas instâncias de supervisão supranacional para aferir o grau de compatibilidade da ordem interna às obrigações convencionais.

Em decorrência do art. 25 (proteção judicial) c/c art. 2 (dever de adotar disposições de direito interno) da Convenção, a Corte reconhece que todos os magistrados nacionais possuem um poder-dever de realizar a confrontação da legislação nacional em relação às obrigações internacionais assumidas pelo país. Esta faculdade impõe aos togados um dever de dupla verificação de compatibilidade vertical (controle de constitucionalidade e controle de convencionalidade). É justamente em face deste poder-dever que os magistrados devem, a despeito da existência de decisão vinculante emanada da Suprema Corte, negar vigência às regras infraconstitucionais das inelegibilidades que sejam consideradas incompatíveis com a obrigação conferida aos cidadãos nos termos do art. 23.2 da Convenção.

Para fins de análise neste trabalho, as hipóteses de inelegibilidade definidas no art. $1^{\circ}$ da LC n. 64/90 foram reunidas em cinco grupos distintos.

O primeiro grupo reúne as situações em que os cidadãos não ostentam as condições exigidas para gozarem dos direitos políticos passivos (alínea “a”) e o último grupo, aqueles que devem se desincompatibilizar em determinado período antes do pleito (incs. 
II a VII). A regulamentação destes requisitos decorre da liberdade de conformação dos Estados para empreender as escolhas do modelos eleitorais a serem adotados. Em análise preliminar, pode-se perceber que não há violação evidente em relação às garantias convencionais. No entanto, esta análise poderia ser mais aprofundada se fosse empreendida análise de proporcionalidade, nos termos fixados no caso Castañeda Gutman vs. Estados Unidos Mexicanos.

Por outro lado, todas as inelegibilidades cominadas nas alíneas "b" à "q" não poderiam ser integralmente aplicadas na forma em que estão definidas na legislação brasileira. O segundo grupo (agentes políticos cassados e/ou que tenham renunciado) e o quarto grupo (agentes que sofreram condenações administrativas e/ou disciplinares) revelam-se flagrantemente inconvencionais porque projetam as graves restrições aos direitos políticos passivos sem que haja um pronunciamento do órgão judicial competente. Desta forma, uma das hipóteses que resultou no maior número de afastamentos nas eleições de 2012 e 2014 (inelegibilidade decorrente de rejeição de contas, alínea “g”) revela-se de todo incompatível com a Convenção Americana de Direitos Humanos.

O terceiro grupo reúne hipóteses em que as inelegibilidades decorrem de sentenças judiciais. No entanto, deste grupo, as únicas hipóteses que poderiam passar pelo crivo de convencionalidade dizem respeito às inelegibilidades decorrentes de decisão criminal. É desta forma porque não basta que as decisões tenham sido proferidas em processos judiciais, mas esses processos devem ter índole criminal (processo penal), do contrário, igualmente essas condenações não poderiam ter o condão de suspender o gozo dos direitos políticos passivos.

Por fim, mesmo em relação às decisões proferidas em processos penais, reputa-se ser flagrantemente inconvencional qualquer antecipação dos efeitos da condenação criminal (ou seja, antecipação da inelegibilidade para momento anterior ao trânsito em julgado da decisão), pois do contrário estar-se-ia diante de flagrante ofensa ao princípio da presunção de inocência, fundamento das garantias penais insculpido no art. 8.2 do texto convencional.

O que se percebe é que, em uma análise peremptória, a quase totalidade do regime das inelegibilidades infraconstitucionais não resiste ao controle de convencionalidade. Afirmar isso permite, não somente, dirigir uma crítica contundente ao moralismo que o movimento do "fichalimpismo" provocou no âmbito do Judiciário (COSTA, 2013, p. 17; ESPÍNDOLA, 2013). Mas significa, a um só tempo, fornecer subsídios técnicos para que os juízes eleitorais possam deixar de aplicar as regras flagrantemente inconvencionais e, se for o caso, autoriza que os prejudicados possam postular o reconhecimento da violação ao direito de sufrágio passivo perante as instâncias de controle supranacional.

Em última instância, trata-se de afirmar uma nova frente de batalha contra o papel assumido pelo Judiciário como alter ego da sociedade. Afinal de contas, acredita-se que a aura de incorruptibilidade conferida às cortes (em detrimento das demais esferas de poder) acaba por intensificar o processo de esvaziamento e de demonização da política 


\section{e do político. Ao fim e ao cabo, a própria democracia é quem está sob ataque e pre- cisa ser reabilitada.}

\section{NOTAS}

* Esta pesquisa foi parcialmente financiada com recursos provenientes do CNPq (Projeto 486144/2011-9, Edital Universal 14/2011).

1 Posteriormente à conclusão da pesquisa que ensejou o presente artigo, Marcelo Ramos Peregrino Ferreira (juiz Eleitoral Titular do TRE/SC entre 2012-2014) defendeu na PUC-SP, em 4 de setembro de 2014, dissertação sobre o controle de convencionalidade da Lei da Ficha Limpa. Em um segundo momento, já posterior à submissão do presente artigo, o referido texto tornou-se livro, sendo a primeira monografia a correlacionar controle de convencionalidade e direito eleitoral em solo brasileiro (cf. FERREIRA, 2015).

2 As três ações do controle concentrado (ADI n. 4.578, ADC n. 29 e ADC n. 30) foram julgadas conjuntamente, razão pela qual os três acórdãos são idênticos e as citações farão menção às três decisões.

3 "La Contraloría General de la República es un órgano con rango constitucional que a partir de la entrada en vigencia de la Constitución de la República Bolivariana de Venezuela de 1999, pasó a ser parte del Poder Ciudadano. Este Poder, el cual es ejercido por el Consejo Moral Republicano, está integrado por la Defensoría del Pueblo, el Ministerio Público y la Contraloría General de la República. Siguiendo lo dispuesto en el artículo 274 constitucional, la existencia de esta nueva rama del Poder Público tiene entre otras atribuciones la prevención, investigación y sanción de los hechos que atenten contra la ética pública y la moral administrativa, y velar por la buena gestión y la legalidad en el uso del patrimonio público.” (CorteIDH, 2011, § 31, p. 14)

4 Art. $1^{\circ}$ São Inelegíveis: I - para qualquer cargo: a) os inalistáveis e os analfabetos.

5 b) os membros do Congresso Nacional, das Assembleias Legislativas, da Câmara Legislativa e das Câmaras Municipais, que hajam perdido os respectivos mandatos por infringência do disposto nos incisos I e II do art. 55 da Constituição Federal, dos dispositivos equivalentes sobre perda de mandato das Constituições Estaduais e Leis Orgânicas dos Municípios e do Distrito Federal, para as eleições que se realizarem durante o período remanescente do mandato para o qual foram eleitos e nos oito anos subsequentes ao término da legislatura.

6 c) o Governador e o Vice-Governador de Estado e do Distrito Federal e o Prefeito e o Vice-Prefeito que perderem seus cargos eletivos por infringência a dispositivo da Constituição Estadual, da Lei Orgânica do Distrito Federal ou da Lei Orgânica do Município, para as eleições que se realizarem durante o período remanescente e nos 8 (oito) anos subsequentes ao término do mandato para o qual tenham sido eleitos.

7 k) o Presidente da República, o Governador de Estado e do Distrito Federal, o Prefeito, os membros do Congresso Nacional, das Assembleias Legislativas, da Câmara Legislativa, das Câmaras Municipais, que renunciarem a seus mandatos desde o oferecimento de representação ou petição capaz de autorizar a abertura de processo por infringência a dispositivo da Constituição Federal, da Constituição Estadual, da Lei Orgânica do Distrito Federal ou da Lei Orgânica do Município, para as eleições que se realizarem durante o período remanescente do mandato para o qual foram eleitos e nos 8 (oito) anos subsequentes ao término da legislatura. 
8 f) os que forem declarados indignos do oficialato, ou com ele incompatíveis, pelo prazo de 8 (oito) anos.

9 g) os que tiverem suas contas relativas ao exercício de cargos ou funções públicas rejeitadas por irregularidade insanável que configure ato doloso de improbidade administrativa, e por decisão irrecorrível do órgão competente, salvo se esta houver sido suspensa ou anulada pelo Poder Judiciário, para as eleições que se realizarem nos 8 (oito) anos seguintes, contados a partir da data da decisão, aplicando-se o disposto no inciso II do art. 71 da Constituição Federal, a todos os ordenadores de despesa, sem exclusão de mandatários que houverem agido nessa condição.

10 i) os que, em estabelecimentos de crédito, financiamento ou seguro, que tenham sido ou estejam sendo objeto de processo de liquidação judicial ou extrajudicial, hajam exercido, nos 12 (doze) meses anteriores à respectiva decretação, cargo ou função de direção, administração ou representação, enquanto não forem exonerados de qualquer responsabilidade.

$11 \mathrm{~m}$ ) os que forem excluídos do exercício da profissão, por decisão sancionatória do órgão profissional competente, em decorrência de infração ético-profissional, pelo prazo de 8 (oito) anos, salvo se o ato houver sido anulado ou suspenso pelo Poder Judiciário.

12 o) os que forem demitidos do serviço público em decorrência de processo administrativo ou judicial, pelo prazo de 8 (oito) anos, contado da decisão, salvo se o ato houver sido suspenso ou anulado pelo Poder Judiciário.

13 q) os magistrados e os membros do Ministério Público que forem aposentados compulsoriamente por decisão sancionatória, que tenham perdido o cargo por sentença ou que tenham pedido exoneração ou aposentadoria voluntária na pendência de processo administrativo disciplinar, pelo prazo de 8 (oito) anos.

14 d) os que tenham contra sua pessoa representação julgada procedente pela Justiça Eleitoral, em decisão transitada em julgado ou proferida por órgão colegiado, em processo de apuração de abuso do poder econômico ou político, para a eleição na qual concorrem ou tenham sido diplomados, bem como para as que se realizarem nos 8 (oito) anos seguintes.

15 j) os que forem condenados, em decisão transitada em julgado ou proferida por órgão colegiado da Justiça Eleitoral, por corrupção eleitoral, por captação ilícita de sufrágio, por doação, captação ou gastos ilícitos de recursos de campanha ou por conduta vedada aos agentes públicos em campanhas eleitorais que impliquem cassação do registro ou do diploma, pelo prazo de 8 (oito) anos a contar da eleição.

$16 \mathrm{n}$ ) os que forem condenados, em decisão transitada em julgado ou proferida por órgão judicial colegiado, em razão de terem desfeito ou simulado desfazer vínculo conjugal ou de união estável para evitar caracterização de inelegibilidade, pelo prazo de 8 (oito) anos após a decisão que reconhecer a fraude.

17 p) a pessoa física e os dirigentes de pessoas jurídicas responsáveis por doações eleitorais tidas por ilegais por decisão transitada em julgado ou proferida por órgão colegiado da Justiça Eleitoral, pelo prazo de 8 (oito) anos após a decisão, observando-se o procedimento previsto no art. 22.

18 h) os detentores de cargo na administração pública direta, indireta ou fundacional, que beneficiarem a si ou a terceiros, pelo abuso do poder econômico ou político, que forem condenados em decisão transitada em julgado ou proferida por órgão judicial colegiado, para a eleição na qual concorrem ou tenham sido diplomados, bem como para as que se realizarem nos 8 (oito) anos seguintes.

19 1) os que forem condenados à suspensão dos direitos políticos, em decisão transitada em julgado ou proferida por órgão judicial colegiado, por ato doloso de improbidade administrativa que importe lesão ao patrimônio público e enriquecimento ilícito, desde a condenação ou o trânsito em julgado até o transcurso do prazo de 8 (oito) anos após o cumprimento da pena.

20 e) os que forem condenados, em decisão transitada em julgado ou proferida por órgão judicial colegiado, desde a condenação até o transcurso do prazo de 8 (oito) anos após o cumprimento da pena, pelos crimes: 1. contra a economia popular, a fé pública, a administração pública e o patrimônio público; 2. contra o patrimônio privado, o sistema financeiro, o mercado de capitais e os previstos na lei que regula a falência; 3. contra o meio ambiente e a saúde pública; 4. eleitorais, para os quais a lei comine pena privativa de liberdade; 5. de abuso de autoridade, nos casos em que houver 
condenação à perda do cargo ou à inabilitação para o exercício de função pública; 6. de lavagem ou ocultação de bens, direitos e valores; 7. de tráfico de entorpecentes e drogas afins, racismo, tortura, terrorismo e hediondos; 8 . de redução à condição análoga à de escravo; 9. contra a vida e a dignidade sexual; e 10. praticados por organização criminosa, quadrilha ou bando.

\section{REFERÊNCIAS BIBLIOGRÁFICAS}

AGRA, Walber de Mora. Inconstitucionalidades da incidência da Lei Complementar n. 135/2010. In: . AGRA, Walber de Moura. Temas polêmicos de direito eleitoral. Belo Horizonte: Fórum, 2012. p. 11-32. AGUILAR C., Gonzalo. El control de convencionalidad: análisis en derecho comparado. Revista de Direito GV, São Paulo, v. 9, n. 2, p. 721-754, jul.-dez. 2013.

ALBANESE, Susana (coord.). El control de convencionalidad. Buenos Aires: Ediar, 2008.

BASTOS JR, Luiz Magno Pinto; CAMPOS, Thiago Yukio Guenka. Para além do debate em torno da hierarquia dos tratados: do duplo controle vertical das normas internas em razão da incorporação dos tratados de direitos humanos. Revista da Faculdade de Direito da UERJ, Rio de Janeiro, v. 1, n. 19, jun./dez. 2011.

Disponível em: <http://www.e-publicacoes.uerj.br/index.php/rfduerj/article/viewFile/1717/1331>. Acesso em: 10 jul. 2015.

; GONCALVES, Jair Domingos. O status atribuido aos tratados de direitos humanos realmente

importa? Analise do posicionamento do STF sobre o tema. Revista Eletronica Direito e Politica, Itajai, v. 8, n. 3, p. 2390-2423, $3^{\circ}$ quadrimestre de 2013. Disponivel em:

<http://www6.univali.br/seer/index.php/rdp/article/viewFile/5453/2878>. Acesso em: 10 jul. 2015. BRASIL. Supremo Tribunal Federal. Ação Declaratória de Constitucionalidade n. 29. Relator Ministro Luiz Fux. Julgada em 16 de fevereiro de 2012. DJe 29 de junho de 2012. Disponível em: < http://redir.stf.jus.br/ paginadorpub/paginador.jsp?docTP=TP\&docID=2243342>. Acesso em: 13 de jun. 2014.

BRASIL. Supremo Tribunal Federal. Ação Declaratória de Constitucionalidade n. 30. Relator Ministro Luiz Fux. Julgada em 16 de fevereiro de 2012. DJe 29 de junho de 2012. Disponível em: < http://redir.stf.jus.br/ paginadorpub/paginador.jsp?docTP=TP\&docID=2243411>. Acesso em: 13 de jun. 2014.

BRASIL. Supremo Tribunal Federal. Ação Direita de Inconstitucionalidade n. 4.578. Relator Ministro Luiz Fux. Julgada em 16 de fevereiro de 2012. DJe 29 de junho de 2012. Disponível em: <http://redir.stf.jus.br/ paginadorpub/paginador.jsp?docTP=TP\&docID=2257978>. Acesso em: 13 de jun. 2014.

CAMARGO, Monica Ovinski de. Princípio da presunção de inocência no Brasil: o conflito entre punir e libertar. Rio de Janeiro: Lumen Juris, 2005.

CÂNDIDO, Joel José. Direito eleitoral brasileiro. 15. ed. São Paulo: Edipro, 2012.

COÊLHO, Marcus Vinicius Furtado. Direito Eleitoral e processo eleitoral. 3. ed. Rio de Janeiro: Renovar, 2012. CORTE Interamericana de Direitos Humanos. Caso Castañeda Gutman vs. Estados Unidos Mexicanos. Excepciones Preliminares, Fondo, reparaciones y costas. Sentencia de 6 de agosto de 2008, Serie C n. 184. Disponível em: $<$ http://www.corteidh.or.cr/docs/casos/articulos/seriec_184_esp.pdf>. Acesso em: 15 jun. 2013.

. Caso López Mendoza vs. Venezuela. Fondo, reparaciones y costas. Sentencia de 1 de septiembre de 2011.

Serie C n. 233. Disponível em: <http://corteidh.or.cr/docs/casos/articulos/seriec_233_esp.pdf>. Acesso em: 12 maio 2013.

COSTA, Adriano Soares da. Instituições de direito eleitoral: v. 1: teoria da inelegibilidade, direito processual eleitoral. 9. ed. Belo Horizonte: Fórum, 2013.

DALLA VIA, Alberto Ricardo. Los derechos políticos en el Sistema Interamericano de Derechos Humanos. Revista Justicia Electoral, v. 1, n. 8, p. 15-79, 2011.

ESPÍNDOLA, Ruy Samuel. A constituição de 1988 como garantia da democracia brasileira. O papel dos princípios constitucionais. Aportes comemorativos de seus 25 anos. Revista Brasileira de Direito Eleitoral, Belo Horizonte, a. 5, n. 9, p. 169-182, jul./dez. 2013.

FERREIRA, Marcelo Peregrino. O Controle de convencionalidade da Lei da Ficha Limpa: direitos políticos e inelegibilidades. Rio de Janeiro: Lumen Juris, 2015.

FERRER MAC-GREGOR, Eduardo. Eficacia de la sentencia interamericana y la cosa juzgada internacional: vinculación directa hacia las partes (res judicata) e indirecta hacia los Estados Parte de la Convención 
Americana (res interpretata) (sobre el descumprimiento del Caso Gelman vs. Uruguay). Estudios Constitucionales, a. 11, n. 2, p. 641-694, 2013.

GALVIS, Maria Clara; SALAZAR, Katya. La jurisprudencia internacional y el procesamiento de violaciones de derechos humanos por tribunales nacionales. Washington D.C., jan. 2007. Disponível em: <http://www.dplf.org/ uploads/1191599742.pdf>. Acesso em: 25 set. 2010.

GOMES, José Jairo. Direito eleitoral. 9. ed. São Paulo: Atlas, 2013.

GUEDES, Néviton. Comentário aos artigos 14 a 16. In: CANOTILHO, J.J. Gomes; MENDES, Gilmar; SARLET, Ingo; STRECK, Lenio L. et al. (coords.). Comentários à Constituição do Brasil. São Paulo: Saraiva/Almedina, 2013. p. 654-689.

HITTERS, Juan Carlos. ¿Son vinculantes los pronunciamientos de la Comisión y de la Corte Interamericana de Derechos Humanos? (control de constitucionalidad y convencionalidad). Revista Iberoamericana de Derecho Procesal Constitucional, n. 10, p. 131-156, jul./dez. 2008. Disponível em: <http://www.corteidh.or.cr/ tablas/r25295.pdf>. Acesso em: 30 jul. 2015.

LONDOÑO LÁZARO, Maria Carmelina. El principio de legalidad y el control de convencionalidad de las leyes: confluencias y perspectivas en el pensamiento de la Corte Interamericana de Derechos Humanos. Boletín Mexicano de Derecho Comparado, ano LXIII, n. 128, p. 761-814, maio/ago. 2010. Disponível em: $<$ http://dialnet.unirioja.es/servlet/articulo?codigo=3212723>. Acesso em: 20 mar. 2013.

LUCCHETTI, Alberto J.. Los jueces y algunos caminos del control de convencionalidad. In: ALBANESE, Susana (org.). El control de convencionalidad. Buenos Aires: Ediar, 2008. p. 131-162.

LUPI, André L. P. B.; BASTOS JR, L. M. P. A interpretação da norma internacional em conformidade com seu contexto: uma proposta para aplicação do direito internacional pelos tribunais brasileiros. XVII Congresso Nacional do CONPEDI, 2008, Brasília. Anais do XVII Congresso Nacional do CONPEDI. Florianópolis: Fundação José Boiteux, 2008. p. 2490-2513.

MAZZUOLI, Valerio de Oliveira. Teoria geral do controle de convencionalidade no direito brasileiro. In: MARINONI, L.G.; MAZZUOLI, V. de O. (org.). Controle de convencionalidade: um panorama latino-americano. Brasília: Gazeta Jurídica, 2013. p. 3-56.

MENDES, Antonio Carlos. Introdução à teoria das inelegibilidades. São Paulo: Malheiros, 1994.

NOGUEIRA ALCALÁ, Humberto. El debido proceso en la Constitución y el sistema interamericano: doctrina y jurisprudencia. 2. ed. Santiago: Librotecnia, 2012.

Humberto. Informe pericial Caso López Mendoza vs. Venezuela de Dr. Humberto Nogueira Alcalá. Estudios constitucionales, a. 9, n. 1, p. 339-362, 2011.

RAMOS, André de Carvalho. Teoria geral dos direitos humanos na ordem internacional. Rio de Janeiro: Renovar, 2005. REY CANTOR, Ernesto. Jurisdicción constitucional y control de convencionalidad de las leyes. X Congreso Iberoamericano de Derecho Constitucional, Lima (Peru), 16-19 set. 2009.

SAGÜES, Nestor Pedro. Obligaciones internacionales y control de convencionalidad. Estudios Constitucionales, ano 8, n. 1, p. 117-136, 2010. Disponível em: <http://www.cecoch.cl/docs/pdf/revista_ano8_1_2010/ articulo_4.pdf>. Acesso em: 20 set. 2010.

SALGADO, Eneida Desire. Princípios constitucionais eleitorais. Belo Horizonte: Fórum, 2010.

SARLET, Ingo Wolfgang. Notas sobre as relações entre a Constituição Federal de 1988 e os tratados internacionais de direitos humanos na perspectiva do assim chamado controle de convencionalidade. In:

MARINONI, L.G.; MAZZUOLI, V. de O. (org.) Controle de convencionalidade: um panorama latino-americano. Brasília: Gazeta Jurídica, 2013. p. 87-114.

A eficácia dos direitos fundamentais: uma teoria geral dos direitos fundamentais na perspectiva constitucional. 12. ed. Porto Alegre: Livraria do Advogado, 2015.

SCHEPIS, Marcelo. La influencia de los tratados internacionales en el derecho interno. El control de convencionalidad. XXV Congreso Nacional de Derecho Procesal. Buenos Aires, 11-13 nov. 2009. Disponível em: $<$ http://www.procesal2009bsas.com.ar/ponencias-consti-proceso.html >. Acesso em: 25 set. 2010.

ZILIO, Rodrigo López. Direito eleitoral: noções preliminares; elegibilidade e inelegibilidades; ações eleitorais; processo eleitoral. 3. ed. Porto Alegre: Verbo Jurídico, 2012. 


\author{
Florianópolis - SC - Brasil \\ Imagnolaunivali.br
}

São José - SC - Brasil rmslaunivali.br
Luiz Magno Pinto Bastos Júnior

Professor de Direito Constitucional e Direito Processual Constitucional na graduação (Direito) e no Programa de Mestrado e Doutorado em ClênCia Jurídica da Universidade do VAlE do ItAJAí.

\section{Rodrigo Mioto dos Santos}

Professor de Direito Penal e Direito Processual

Penal na Universidade do Vale do Itajaí.

Coordenador do Observatório do Sistema INTERAMERICANO DE DIREITOS HUMANOS. 
